\title{
The physical and chemical characteristic of 30 soil samples from kuala lumpur and selangor: a discriminative study
}

\begin{abstract}
The use of soil as a form of forensic trace evidence has proven to be very useful due to its versitality and high variablility at differnt locations. Often discriminated based on their physical (color, particle size, distribution) and chemical ( $\mathrm{pH}$, percentage of combustible organic content and soil trace metal) characteristics, the latter is commonly employed as a confirmatory test due to the indivualised and accurate information generated upon analysis, particularly from the analysis using ICP-MS (Inductively Coupled Plasma-Mass Spectrometry) for trace metal analysis in soil. In this study, soil samples were collected from thirty different locations in Selangor and Kuala Lumpur and were analyzed in terms of their physical and chemical similarity and differences. Kruskal-Wallis test, employed to test the physical (color and particle size distribution) demonstrated that there were significant differences in terms of color between soil from different sampling locations and for particle size distribution. Upon the application of the Decision Tree test that was built using C5.0 algorithm on the physical characteristics data from soil samples, 24 out of 30 samples were differentiated. In terms of chemical characteristics, Kruskal-Wallis tests on $\mathrm{pH}$ and soil percentage of combustible organic content showed that there were significant differences between soil from different sampling locations, with $\mathrm{pH}\left[\mathrm{X}^{2}(29, \mathrm{~N}=90)=85.849, \mathrm{p}<0.01\right]$ and percentage of combustible organic content $\left[\mathrm{X}^{2}(29, \mathrm{~N}=90)=81.825, \mathrm{p}<0.01\right]$. For trace metal analysis, the ICP-MS data for each soil sample was analyzed using modified equal interval categorization method and Choropleth mapping in the form of a table and results revealed that all of the samples were individualized successfully. This study proved that with the coupling of physical and chemical characteristics of soil, any soil samples can be discriminated from each other when sampled at different locations.
\end{abstract}

Keywords: ICP-MS, physical characteristics, chemical characteristics, modified equal interval categorization method, modified choropleth mapping, kruskal-wallis tests
Volume 2 Issue 6 - 2016

Gina Francesca Gabriel, Edison Eukun Sage, Khairul Osman, Atiah Ayunni Abdul Ghani, Aziz Ishak, Pua Hiang, Noor Hazfalinda Hamzah Faculty of Health Sciences, Universiti Kebangsaan Malaysia, Malaysia

Correspondence: Noor Hazfalinda Hamzah, Forensic Science Program, Faculty of Health Sciences, Universiti Kebangsaan Malaysia, Jalan Raja Muda Abdul Aziz, 50300 Kuala Lumpur, Malaysia,Tel 60I2-2767280,Email raviera@yahoo.com

Received: June 06, 2016 | Published: September 27, 2016

\section{Introduction}

Soil is one of the most common natural elements encountered by humans in their daily lives, either consciously or unconsciously. Soil is defined as 'a material, which can be more or less friable and loose, in which the plant can obtain nourishment, foothold and other essential growth factors by means of their roots'. ${ }^{1}$ Soil is categorized as trace evidence in forensic science. The earliest written record pertaining to the application of soil in forensic science dates back to 1857 by a certain Hans Gross. ${ }^{2}$ Although soil sample may look simple, if analyzed the right way, it can be deemed powerful, forensically. Soil possesses a range of characteristics that facilitates its usage as crucial forensic evidence. This includes the ability of soil to be individualized easily based on sampling location and content. In addition, the analytical process that follows for soil samples are non-tedious, direct, and easy and time savvy. It is also one of the least familiar trace evidence particularly to a criminal, making it highly likely to be encountered in forensic cases, untouched. ${ }^{3}$ In Malaysia, although there have been many researchers conducted using soil, particularly for agricultural purposes, there has been little or no work steering towards forensic soil analysis in the country. Thus, this project was developed to fill the gap, by looking into various soil samples across the Klang Valley, focusing on the ability of simple techniques that utilizes the characteristics of soil such as particle size distribution, color, $\mathrm{pH}$, percentage of organic content and trace metal analysis to differentiate soil samples originating from different locations in Selangor and Kuala Lumpur.

\section{Materials and methods}

\section{Soil sampling}

Firstly, a spot in the selected location was identified and a $30 \times$ $30 \mathrm{~cm}^{2}$ spot was measured on the soil and marked to make it visible. Then, $1 \mathrm{~cm}$ of the soil was dug using a trowel and collected. The soil sample was then placed into a plastic container and labeled.

\section{Analysis of soil physical characteristics}

Particle size distribution: Two different sieve sizes $(0.60 \mathrm{~mm}$ and $0.18 \mathrm{~mm}$ ), scales and spatula were used in this section. Firstly, $5 \mathrm{~g}$ of soil was weighed and placed into the sieve. The soil was sieved until 
there was no more soil escaping through the sieve. The remaining soil on the sieve was weighed and the soil mass was recorded. The entire process was repeated three times in order to produce triplicate measurements. ${ }^{4}$

Color: $3 \mathrm{~g}$ of soil sample from each triplicate were selected and moistened with distilled water. The best match for each soil compared against the color chips was determined using the Munsell color book. These steps were repeated on soils that were

\section{Oven dried}

2. Decomposed with $30 \%$ hydrogen peroxide and

3. Ignited at $650 \mathrm{oC}$ for 30 minutes using an electric furnace. ${ }^{5}$

\section{Analysis of soil chemical properties}

pH: $6 \mathrm{~g}$ of soil sample was taken out from its original container and divided into three portions and placed into three different beakers. A 1:1 ratio of distilled water to soil sample was added into each beaker and mixed using a glass rod. The samples were left for about 10 minutes before measuring their $\mathrm{pH}$ using a $\mathrm{pH}$ meter.

Percentage of organic content: About $5 \mathrm{~g}$ of soil sample was weighed and placed into petri dish. The petri dish containing the soil sample was then placed into an oven and heated at $105^{\circ} \mathrm{C}$ until it was dried. Then, the dried soil sample was weighed before being placed into an electrical furnace to undergo ignition at $650^{\circ} \mathrm{C}$ for 30 minutes. The soil sample was then taken out and weighed. ${ }^{6}$ The percentage of organic content was then calculated using the formula:

$\begin{array}{ll}\text { (weight of soil sample after } \\ \text { moisture removal, before the } \\ \text { ignition) - (weight of soil } \\ \text { sample after ignition) }\end{array} \times 100$

Trace metal analysis: $5 \mathrm{~g}$ of dried soil sample was sieved using a $0.18 \mathrm{~mm}$ sieve and placed into a $100 \mathrm{~mL}$ beaker. $10 \mathrm{~mL}$ of conc. HNO3 (69-70\%) was added into the sample and heated at $100 \mathrm{oC}$ using a hotplate. When the solution becomes almost dry, $5 \mathrm{~mL}$ conc. HNO3 (69-70\%) was added to the sample. This process was repeated until the clear soil sample solution was obtained (regardless of color). The clear solution was then cooled and filtered using a filter paper. The filtrate was diluted with $100 \mathrm{~mL}$ distilled water, from which 15 $\mathrm{mL}$ of the solution was then transferred into a Falcon tube for ICP-MS (Inductively Coupled Plasma-Mass Spectrometry) analysis. These processes were repeated for the other soil samples.

\section{Results and discussion}

The collected data for the physical characteristics of soil (soil particle size distribution and soil color) and chemical characteristics of soil ( $\mathrm{pH}$ and percentage of organic material in soil) were found to be not normally distributed. This is highly likely to be due to the insufficient sample size that failed to reflect the true distribution of each particular variable. There were only 3 sets of data for each studied variables at each location. For both characteristics, KruskalWallis test was then conducted and results indicated that there were significant differences for each variable between each soil sampling location.

\section{Discrimination of $\mathbf{3 0}$ soil samples from Selangor and Kuala Lumpur using the physical characteristics of soil}

\section{a. Particle size distribution analysis}

There are significant differences for particle size distribution between each soil sampling location.
i. $>0.6 \mathrm{~mm}(\%), \mathrm{X}^{2}(29, \mathrm{~N}=90)=88.802, \mathrm{p}<0.01$
ii. between $0.6 \mathrm{~mm}$ to $0.18 \mathrm{~mm}(\%), \mathrm{X}^{2}(29, \mathrm{~N}=90)=88.541, \mathrm{p}<0.01$
iii. $<0.18 \mathrm{~mm}(\%), \mathrm{X}^{2}(29, \mathrm{~N}=90)=88.792, \mathrm{p}<0.01$
b. Soil color analysis

There are significant differences in soil color for each pre-treatment between each soil sampling locations.

$$
\begin{aligned}
& \text { i. } \text { dry, } X^{2}(29, N=90)=78.540, p<0.01 \\
& \text { ii. } \text { wet, } X^{2}(29, N=90)=86.105, p<0.01 \\
& \text { iii. } \mathrm{H}_{2} \mathrm{O}_{2}, \mathrm{X}^{2}(29, \mathrm{~N}=90)=87.843, \mathrm{p}<0.01 \\
& \text { iv. furnace, } \mathrm{X}^{2}(29, \mathrm{~N}=90)=89.000, \mathrm{p}<0.01
\end{aligned}
$$

A Decisional Tree test of C5.0 algorithm was then conducted to individualize each soil sample. Out of the 30 samples, 24 samples were found to be distinguishable from each other while the remaining 6 failed to be discriminated (Jalan Tugu (13), Rasa (16), Setapak (8), KTM Putra (11), KTM Bangi (7) and Monorel Maharajalela (17)). From the results of this study, $80 \%$ of the soil samples were found to be distinguishable based on their physical characteristics. ${ }^{8}$

\section{Discrimination of $\mathbf{3 0}$ soil samples from Selangor and Kuala Lumpur using the chemical characteristics of soil}

Soil pH analysis: There are significant differences for soil $\mathrm{pH}$ between each soil sampling locations, with $\mathrm{X}^{2}(29, \mathrm{~N}=90)=85.849, \mathrm{p}<0.01$.

Soil percentage of organic content analysis: There are significant differences for soil percentage of organic content between each soil sampling locations, with $\mathrm{X}^{2}(29, \mathrm{~N}=90)=81.825, \mathrm{p}<0.01$. Upon analysis of the accumulated chemical characteristics data $(\mathrm{pH}$ and organic content analysis) using the Decision Tree test of C5.0 algorithm, 15 out of the 30 soil samples were distinguishable from each other. The other 15 samples could not be discriminated (Jalan Tugu (13), KTM Putra (11), Kuang (28), Batang Kali (30), Plaza Rah (18), Sungai Buloh (27), Setapak (8), Tun Sambathan (3), Bandar Tasik Selatan (23), KTM Bangi (7), KTM Sentul (9), Serdang (6), Serendah (20), LRT Bukit Jalil (25) and LRT Sungai Besi (29)). Also, 7 pairs / groups of soil sample characteristics based on locations (Jalan Tugu (13) - KTM Putra (11) - Kuang (28), Batang Kali (30) - KTM Putra (11) - Plaza Rah (18) - Sungai Buloh (27), Kuang (28) Setapak (8) - Tun Sambathan (3), Bandar Tasik Selatan (23) - Batang Kali (30), KTM Sentul (9) - Bandar Tasik Selatan (23), Serdang (6) - Serendah (20) and LRT Bukit Jalil (25) - LRT Sungai Besi (29)) failed to be distinguished. The pair or group of soil samples that could not be discriminated using the Decision Tree test of C5.0 algorithm analysis of $\mathrm{pH}$ and percentage of organic content were successfully discriminated using equal interval categorization method and modified Choropleth mapping in the form of a table. The samples that possess different colors are considered to be different, as illustrated in Table 1. 
Table I Discrimination analysis of soil samples using equal interval categorization method and modified Choropleth mapping in table form

\begin{tabular}{|c|c|c|c|}
\hline $\begin{array}{l}\text { Group/Pair of Samples that have not yet } \\
\text { been Discriminated }\end{array}$ & Pair & $\begin{array}{l}\text { Number and Type of Element } \\
\text { that cannot be Discriminated }\end{array}$ & $\begin{array}{l}\text { Number of Element } \\
\text { that can be } \\
\text { Discriminated }\end{array}$ \\
\hline \multirow{3}{*}{ Jalan Tugu (I3) - KTM Putra (I I) - Kuang (28) } & $11-13$ & $\begin{array}{l}\text { II (Cd, Be, Li, Mg, Mo, Sb, TI, V, Ni, Ti, } \\
\text { Se) }\end{array}$ & 9 \\
\hline & $11-18$ & $3(\mathrm{Ni}, \mathrm{Ti}, \mathrm{Se})$ & 17 \\
\hline & $13-28$ & $4(\mathrm{~V}, \mathrm{Ni}, \mathrm{Ti}, \mathrm{Se})$ & 16 \\
\hline \multirow{3}{*}{\multicolumn{2}{|c|}{ Batang Kali (30) - KTM Putra (II) - Plaza Rah (I8) II-30 }} & $3(\mathrm{Ni}, \mathrm{Ti}, \mathrm{Se})$ & 17 \\
\hline & & $4(\mathrm{Sr}, \mathrm{Ni}, \mathrm{Ti}, \mathrm{Se})$ & 16 \\
\hline & & $5(\mathrm{Mn}, \mathrm{Be}, \mathrm{Ni}, \mathrm{ti}, \mathrm{Se})$ & 15 \\
\hline \multirow[t]{3}{*}{ - Sungai Buloh (27) } & $11-27$ & $2(\mathrm{Ti}, \mathrm{Se})$ & 18 \\
\hline & $11-30$ & $3(\mathrm{Ni}, \mathrm{Ti}, \mathrm{Se})$ & 17 \\
\hline & $11-18$ & $4(\mathrm{Cd}, \mathrm{Mo}, \mathrm{Ti}, \mathrm{Se})$ & 16 \\
\hline \multirow{3}{*}{ Kuang (28) - Setapak (8) - Tun Sambathan (3) } & $3-8$ & $2(\mathrm{Ni}, \mathrm{Se})$ & 18 \\
\hline & $3-28$ & $2(\mathrm{Ni}, \mathrm{Se})$ & 18 \\
\hline & $8-28$ & $3(\mathrm{Ni}, \mathrm{Ti}, \mathrm{Se})$ & 17 \\
\hline Bandar Tasik Selatan (23) - Batang Kali (30) & $23-30$ & $6(\mathrm{Mn}, \mathrm{Cu}, \mathrm{Co}, \mathrm{NI}, \mathrm{Ti}, \mathrm{Se})$ & 14 \\
\hline KTM Sentul (9) - Bandar Tasik Selatan (23) & $9-23$ & $2(\mathrm{Sr}, \mathrm{Ti})$ & 18 \\
\hline Serdang (6) - Serendah (20) & $6-20$ & $4(\mathrm{Li}, \mathrm{Ni}, \mathrm{Ti}, \mathrm{Se})$ & 16 \\
\hline LRT Bukit Jalil (25) - LRT Sungai Besi (29) & $25-29$ & $4(\mathrm{Cd}, \mathrm{Ni}, \mathrm{Ti}, \mathrm{Se})$ & 16 \\
\hline
\end{tabular}

Trace metal analysis: Kruskal Wallis test could not be performed due to insufficient sets of data. Further testing was conducted using modified equal interval categorization method and Choropleth mapping in the form of a table and results revealed that all of the samples were distinguished successfully.

\section{Discrimination of $\mathbf{3 0}$ soil samples from Selangor and Kuala Lumpur using the physical and chemical characteristics of soil}

By combining all of the data from the physical characteristic and chemical characteristics of soil, all of the 30 soil samples were discriminated successfully as demonstrated in Tables $2 \& 3$. The test with the highest discriminative power was found to be the soil trace metal analysis test using the ICP-MS. The ICP-MS data were standardized using chromium ion concentration and categorized using modified equal interval method and modified Choropleth mapping in the form of a table. On the other hand, the test with the lowest discriminative power was identified to be the $\mathrm{pH}$ test.

Table 2 List of samples that were successfully and not successfully discriminated (physical characteristics)

\begin{tabular}{ll}
\hline Soil Samples that were & Soil Samples that were not \\
Successfully Discriminated & Successfully Discriminated \\
\hline I Pandan Indah & 7 KTM Bangi \\
2 UKM Bangi & 8 Setapak \\
3 Tun Sambathan & I I KTM Putra
\end{tabular}

\begin{tabular}{ll}
\hline 4 KL Sentral & I3 Jalan Tugu, Stesen Komuter KL \\
5 Tasik Titiwangsa & 16 Rasa \\
6 Serdang & 17 Monorel Maharajalela \\
9 KTM Sentul & \\
10 LRT Ampang & \\
12 Pudu \\
14 Bukit Nanas \\
15 Taman Miharja \\
18 Plaza Rah \\
19 Rawang \\
20 Serendah \\
2 I Cheras \\
22 LRT Sri Petaling \\
23 Bandar Tasik Selatan \\
24 Bandar Tun Razak \\
25 LRT Bukit Jalil \\
26 Salak Selatan \\
27 Sungai Buloh \\
28 Kuang \\
29 LRT Sungai Besi \\
30 Batang Kali
\end{tabular}


Table 3 List of samples that were successfully and not successfully discriminated (chemical characteristics except soil trace metal analysis)

\begin{tabular}{ll}
$\begin{array}{l}\text { Soil Samples that were } \\
\text { Successfully Discriminated }\end{array}$ & $\begin{array}{l}\text { Soil Samples that were not } \\
\text { Successfully Discriminated }\end{array}$ \\
\hline I Pandan Indah & 3 Tun Sambathan \\
2 UKM Bangi & 6 Serdang \\
4 KL Sentral & 7 KTM Bangi \\
5 Tasik Titiwangsa & 8 Setapak \\
I0 LRT Ampang & 9 KTM Sentul \\
I2 Pudu & II KTM Putra \\
I4 Bukit Nanas & I3 Jalan Tugu, Stesen Komuter KL \\
I5 Taman Miharja & I8 Plaza Rah \\
16 Rasa & 20 Serendah \\
I7 Monorel Maharajalela & 23 Bandar Tasik Selatan \\
I9 Rawang & 25 LRT Bukit Jalil \\
21 Cheras & 27 Sungai Buloh \\
22 LRT Sri Petaling & 28 Kuang \\
24 Bandar Tun Razak & 29 LRT Sungai Besi \\
26 Salak Selatan & 30 Batang Kali \\
\hline
\end{tabular}

\section{Conclusion}

The discrimination power of the 30 soil samples analyzed in this work was found to lie in the chemical characteristics of soil rather than the physical characteristics of soil. While the physical characteristics of soil only managed to discriminate $80 \%$ of the soil samples to their individual locations of sampling, the chemical characteristics of soil, particularly trace metal analysis using the ICP-MS proved to be $100 \%$ discriminative. The combination of both characteristics was found to be more robust in generating excellent discrimination of soil samples based on their sampling locations across Selangor and Kuala Lumpur.

\section{Acknowledgments}

None.

\section{Conflicts of interest}

None.

\section{References}

1. Jenny H. Factors of soil formation: A system of quantitative pedology, Dover Publication, UK, 1994; pp. 1-320.

2. Ruffell A, McKinley J. Forensic geosciences: applications of geology, geomorphology and geophysics to criminal investigations. Earth-Science Reviews. 2005;69(3-4):235-247.

3. Fitzpatrick RW, Raven MD, Forrester ST. A systematic approach to soil forensics: criminal case studies involving transference from crime scene to forensic evidence. Criminal and Environmental Soil Forensics, 2009; pp. $105-127$.

4. Sugita R, Marumo Y. Screening of soil evidence by a combination of simple techniques: validity of particle size distribution. Forensic Science International. 2001;122(2-3):155-158.

5. Sugita R, Marumo Y. Validity of color examination for forensic soil identification. Forensic Science International. 1996;83(3):201-210.

6. Cox RJ, Peterson HL, Young J, et al. The forensic analysis of soil organic by FTIR. Forensic Sci Int. 2000;108(2):107-116.

7. Bockheim J, Gennadiyev A, Hammer R, et al. Historical development of key concepts in pedology. Geoderma. 2005;124(1):23-36.

8. Lin H, Bouma J, Pachepsky Y, et al. Hydropedology: Synergistic integration of pedology and hydrology. Water Resour Res. 2006; 42: W05301. 